ORIGINAL ARTICLE / ARTIGO ORIGINAL

\title{
Correspondence between overweight and socioeconomic and demographic indicators in the adult Brazilian population
}

\section{Correspondência entre excesso de peso e indicadores socioeconômicos e demográficos na população adulta brasileira}

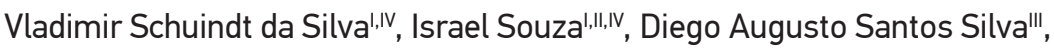 \\ Edio Luiz Petroskill', Maria de Jesus Mendes da Fonsecalv
}

\begin{abstract}
Objective: To verify the correlation between overweight and socioeconomic and demographic indicators among Brazilian adults, using data from the Brazilian Household Budget Survey from 2008/2009. Methods: We analyzed the joint relationships between overweight and socioeconomic and demographic indicators in the Brazilian adult population (99,532,672 individuals), through the multiple correspondence analysis technique. Results: The featured profile of the Brazilian adult population with regard to overweight was correlated with ages from 30 years of the most developed and economically social geographic regions of Brazil; however between genders, the correlation was in the opposite direction in the variables income, education, and subjective issues about life conditions related to food and nutrition security. Conclusion: By the joint relationship between overweight and selected demographic and socioeconomic indicators, the urgency of the development of strategies and/or preventive public health programs of health problems with overweight in the Brazilian adult population is suggested.
\end{abstract}

Keywords: Adult. Cross-sectional studies. Epidemiology. Overweight. Socioeconomic factors. Food security.

'Research Group in Kinanthropometry, Human Performance and Strength Training at Universidade Federal Rural do Rio de Janeiro - Seropédica (RJ), Brazil.

"Instituto Federal de Educação, Ciência e Tecnologia do Rio de Janeiro - Paracambi (RJ), Brazil.

"'Research Group in Kinanthropometry and Human Performance at Universidade Federal de Santa Catarina - Florianópolis (SC), Brazil. "National Public Health School Sergio Arouca, at Fundação Oswaldo Cruz - Rio de Janeiro (RJ), Brazil.

Corresponding author: Vladimir Schuindt da Silva. Universidade Federal Rural do Rio de Janeiro. Departamento de Educação Física e Desportos. Grupo de Pesquisa em Cineantropometria, Performance Humana e Treinamento de Força. BR-465, km 7, s/n, Campus Universitário, CEP: 23890-000, Seropédica, RJ, Brasil. E-mail: vladimirschuindt@hotmail.com

Conflict of interests: nothing to declare - Financial support: none. 
RESUMO: Objetivo: Verificar a correspondência entre excesso de peso e indicadores socioeconômicos e demográficos em adultos no Brasil, por meio dos dados da Pesquisa de Orçamentos Familiares do período de 2008/2009. Métodos: Foram investigadas as relações conjuntas entre excesso de peso e indicadores socioeconômicos e demográficos na população adulta brasileira ( 99.532 .672 indivíduos), por meio da técnica de análise de correspondência múltipla. Resultados: O perfil caracterizado da população adulta brasileira no que se refere ao excesso de peso foi correlacionado com idades a partir de 30 anos, das regiões geográficas mais desenvolvidas social e economicamente do Brasil, mas entre os sexos a correlação foi em direção oposta nas variáveis renda, escolaridade e das questões subjetivas sobre as condições de vida referentes à segurança alimentar e nutricional. Conclusão: Por meio das relações conjuntas entre excesso de peso e indicadores socioeconômicos e demográficos selecionadas, sugere-se a urgência do desenvolvimento de estratégias e/ ou programas preventivos de saúde pública dos agravos à saúde ao excesso de peso à população de adultos brasileiros.

Palavras-chave: Adulto. Estudos transversais. Epidemiologia. Sobrepeso. Fatores socioeconômicos. Segurança alimentar e nutricional.

\section{INTRODUCTION}

The recente behavioral changes that took place in many societies around the world, especially regarding dietary patterns and physical activities, have been a significant contribution to the increasing rates of overweight ${ }^{1}$, which now affects $30 \%$ of the adults ${ }^{2}$, with 5 million estimated deaths a year until $2020^{3}$. Population-based surveys ratify the epidemic progress of overweight rates in the world and in Brazil, in the adult population ${ }^{4-7}$. Other studies show the association between socioeconomic and demographic indicators and the reported outcome ${ }^{7,8-10}$. However, most studies analyzing the prevalence of overweight rates and associated factors used association analyses, by simple and multiple linear regressions ${ }^{10}$, as well as logistic and Poisson regressions ${ }^{7-9}$.

In this context, few studies used the correspondence analysis. Even though this methodology is considered to be a descriptive and exploratory technique, which simplifies complex data and produces exhaustive analyses of information that supports conclusions about $\mathrm{it}^{11}$, in this case it allows identifying how the variables are related and which the profile and cluster of specific variables are. Besides, the graphic illustration of the correspondence analysis enables the understanding of inter-related factors addressed to health administrators, who have little contact with the complex regression analyses.

Therefore, this study aimed at verifying the correspondence between overweight and socioeconomic and demographic indicators among adults aged from 20 to 59 years old, 
of both genders in Brazil, by a global analysis with sampling design structured to provide results with external validity.

\section{METHODS}

This study was based on secondary and public domain data, coming from the Household Budget Survey (POF) from 2008/2009 ${ }^{12}$. Data regarding the sampling procedure of the survey were previously described at a specific publication ${ }^{12}$. However, shortly, it is informed that the effective size of the sample in POF 2008/2009 was of 4,696 sectors, corresponding to 55,970 interviewed households. The number of interviewed households per sector was established according to the research area as 12 households in the urban sectors and 16 in rural ones ${ }^{12}$.

In this investigation, a population of adults aged 20 to 59 years old was selected, of both genders, in the five regions of the Brazilian national territory. Individuals with incomplete data, pregnant women and infants were excluded from the analysis, comprising 99,532,672 individuals. Collections and records of the information were performed directly in each of the selected households, with the residentes, by assisted interview recurring to the memory of the informer, for a period of nine consecutive days.

Overweight was verified by the body mass index [BMI = body mass $(\mathrm{kg}) /$ height $\left(\mathrm{m}^{2}\right)$ ] and classified as $\geq 25.00 \mathrm{~kg} / \mathrm{m}^{213}$. Body mass and height were measured in a portable electronic balance for adults (brand not specified by the Brazilian Institute of Geography and Statistics - IBGE), with minimum sensitivity of $100 \mathrm{~g}$, maximum capacity of $150 \mathrm{~kg}$ and portable stadiometer for adults, by KaWe PERSON-CHECK ${ }^{\circledR}$ (KaWe, Germany), accuracy of $0.1 \mathrm{~cm}$ and extension of up to $200 \mathrm{~cm}$, respectively, according to the recommendations in the Manual of the Research Agent ${ }^{12}$.

The demographic and socioeconomic information of this study, extracted from the questionnaires of POF 2008/2009 (POF 1; POF 5 and POF 6) ${ }^{12}$, were: age group (20 to $29 ; 30$ to $39 ; 40$ to 49 and 50 to 59 years old); sex (male and female); color/ ethnicity (white and nonwhite); major regions (North, Northeast, Southeast, South and CenterWest); schooling (0 to 5; 6 to $9 ; 10$ to 12 and $\geq 13$ schooling years); income ( $1 / 2 \leq \mathrm{MW}$; $1 / 2>\mathrm{MW}<2 ; \geq 2 \mathrm{MW}$ ) referring to the federal minimum wage (MW) that was current at the time of POF 2008/2009 (R\$ 415.00) and life conditions (amount of consumed food: it is usually not sufficient; sometimes it is not sufficient; it is always sufficient; type of consumed food: always the wanted type; not always the wanted type; rarely the wanted type).

The bivariate description of socioeconomic and demographic indicators in the studied population was conducted according to BMI $\geq 25.00 \mathrm{~kg} / \mathrm{m}^{2}$, and proportions were compared by the $\chi^{2}$ test, considering a $5 \%$ significance level. The analysis of joint relationships between socioeconomic and demographic indicators and BMI $\geq 25.00 \mathrm{~kg} / \mathrm{m}^{2}$ 
was conducted by the multiple correspondence analysis (MCA), which is a multivariate analysis to explore categorical data, similar to the analysis, but mainly used for the graphic verification of the relationships between variable categories. In this methodology, the studied variable categories are visually represented by perceptual maps, and their correspondence is assessed according to the proximity of these categories (the closer they are, the higher the chances of being associated $)^{11}$. This study also used the symmetric normalization method, applied to know the differences or similarities between the two variables ${ }^{14}$.

The MCA becomes an extension of the correspondence analysis, thus enabling to study the relationship of more than two nominal variables, representing them in a few dimensions, usually two or three. In this study, two dimensions were chosen by the principle of parsimony, since they explained most of the variance in each analysis ${ }^{11}$. MCA transforms qualitative data by associating optinal quantities to them (scores), which allow not only their graphic representation, but also the separation between categories. The measures of discrimination inform about the variables that mostly contribute with the definition of each one of the dimensions, being the most relevant ones in terms of graphic interpretation. However, theory can lead variables with poor discriminatory power to be interpreted in a specific dimension, and it is also possible to consider another variable in a different dimension in comparison to the more discriminatory one. Therefore, variables which not only contribute more to the expected dimension, but that are also simultaneously away from the origin in the graph ${ }^{14}$, are privileged.

The MCA does not define a selection procedure for the variables to composse the final model of the multivariate analysis, such as the automatic selection procedures for multiple regression models. Selection is often conducted based on the subjectivity of the researcher, and also on the theoretical knowledge about the analyzed subject ${ }^{14}$. Therefore, the idea was to identify a combination of variables and categories presenting more stability when represented in the multidimensional space (graph of factors), explaining the higher percentage of variability in the set of data. The closer two variables would be in the graph, the more common would be its joint occurrence. The graph representing two dimensions generates four quadrants. Both dimensions, together, separate the characteristics placed in the upper left quadrant from those in the lower right quadrant, and the ones in the upper right quadrant from those in the lower left quadrant, thus characterizing groups with extremely opposite profiles. The method does not establish the statistical significance of the associations nor assesses the independent effect of each characteristic; however, it combines the advantages of non-linear and multidimensional methods ${ }^{11}$.

The study was approved by the Research Ethics Committee of the Public Health National School, at Fundação Oswaldo Cruz, protocol n. 13/2013. Data were processed and analyzed, stratified by gender wit the statistical software Statistical Package for the Social Sciences (SPSS), version $20.0^{\mathrm{TM} 15}$. 


\section{RESULTS}

The distribution of socioeconomic and demographic conditions of individuals for both analyzed genders according to $\mathrm{BMI} \geq 25.00 \mathrm{~kg} / \mathrm{m}^{2}$ is presented in Table 1 .

By the MCA, the two first dimensions with self-values higher than 1.3 and 1.4, explaining 48.4 and $48.5 \%$ of the variance, were used, being: 31.5 and $30.3 \%$ in the first and 16.8 and $18.1 \%$ in the second dimension, for male and female genders, respectively. The dimension values were stored for subsequent analyses. The choice of two dimensions was provided by the principle of parsimony, since they explained most of the variance in each analysis. The analyses showed there was a higher percentage in the contribution in each variable and in the composition of the first dimension, more influence regarding income, schooling, color/ethnicity and life conditions for both genders. In the second dimension, influence was more related to age, schooling (for both genders) and BMI (only for female participants).

To build the odels, the measures of discrimination of the variables were used (Table 2). Therefore, the models only had the variables whose measures of discrimination were close to or higher than the values of inertia of the dimension. These refer to the variance explained by the dimension; therefore, there is 0.315 and 0.303 of inertia in the first and 0.168 and 0.181 of inertia in the second dimension, for male and female genders, respectively.

The quantification of variable categories in the dimensions of the models occurred by the values of their centroid coordinates (Table 2), which allow the construction of tipologies organized by dimension and positive (signals) and negative loads of the centroid coordinates of each category.

The correlations between variable categories and the formation of clusters can be assessed by analyzing the proximity between points, as presented in Figures 1 and 2, or by the pattern of relationships between these characteristics. Overweight, being the object of this study, located in the upper right quadrant, in both genders, influences the lower right quadrant, for men, and the upper left, for women. In the end, it provided a description with a general profile for individuals aged 30 years old or more, with selfdeclared white color, from the most socially and economically developed regions of the country. However, between genders, the correlation was in the opposite direction for the variables income, schooling and subjective issues of life conditions regarding food and nutritional safety (SAN).

\section{DISCUSSION}

This study aimed at correlating the socioeconomic and demographic characteristics and overweighr rates, in a population-based sample, referring to Brazilian adults aged 30 to 59 years old, by using data from POF $2008 / 2009$, considering that these may have favored 
Table 1. Frequency (\%) of overweight (body mass index $\geq 25.00$ ) according to socioeconomic and demographic characteristics in adults, by sex, Brazil (2008 to 2009).

\begin{tabular}{|c|c|c|c|c|}
\hline \multirow{3}{*}{ Variables* } & \multicolumn{4}{|c|}{ Sex } \\
\hline & \multicolumn{2}{|c|}{ Male } & \multicolumn{2}{|c|}{ Female } \\
\hline & $\mathrm{n}$ & $\%$ & $\mathrm{n}$ & $\%$ \\
\hline \multicolumn{5}{|l|}{ Age } \\
\hline 20 to 29 years old & $5,751,012$ & 36.3 & $4,333,888$ & 28.9 \\
\hline 30 to 39 years old & $6,935,217$ & 54.1 & $6,228,876$ & 45.0 \\
\hline 40 to 49 years old & $6,517,687$ & 56.9 & $7,023,425$ & 54.7 \\
\hline 50 to 59 years old & $4,975,331$ & 59.2 & $5,749,315$ & 61.4 \\
\hline \multicolumn{5}{|l|}{ Income } \\
\hline$\leq 1 / 2 \mathrm{MW}$ & $2,848,931$ & 35.3 & $3,824,633$ & 44.0 \\
\hline $1 / 2>M W<2$ & $11,910,202$ & 48.0 & $12,462,016$ & 47.4 \\
\hline$\geq 2 \mathrm{MW}$ & $9,420,113$ & 60.2 & $7,048,854$ & 43.9 \\
\hline \multicolumn{5}{|l|}{ Schooling } \\
\hline 0 to 5 years & $7,975,184$ & 46.6 & $9,125,910$ & 54.5 \\
\hline 6 to 9 years & $4,390,420$ & 47.5 & $4,133,005$ & 46.5 \\
\hline 10 to 12 years & $8,485,515$ & 52.0 & $7,347,130$ & 40.9 \\
\hline$\geq 13$ years & $3,328,128$ & 57.3 & $2,729,459$ & 36.9 \\
\hline \multicolumn{5}{|l|}{ Color/ethnicity } \\
\hline White & $12,830,730$ & 54.9 & $11,535,971$ & 45.3 \\
\hline Nonwhite & $11,348,516$ & 45.1 & $11,799,532$ & 46.2 \\
\hline \multicolumn{5}{|l|}{ Region } \\
\hline North & $1,751,036$ & 47.6 & $1,646,005$ & 45.3 \\
\hline Northeast & $5,530,203$ & 42.7 & $6,043,682$ & 44.1 \\
\hline Southeast & $10,999,303$ & 52.3 & $10,300,284$ & 46.0 \\
\hline South & $4,068,768$ & 56.2 & $3,650,980$ & 48.7 \\
\hline Center-West & $1,829,937$ & 50.8 & $1,694,552$ & 44.3 \\
\hline \multicolumn{5}{|l|}{ Amount of consumed food } \\
\hline Usually not sufficient & $1,769,752$ & 38.9 & $2,202,225$ & 46.1 \\
\hline Sometimes not sufficient & $5,986,079$ & 44.8 & $6,574,419$ & 46.7 \\
\hline Always sufficient & $16,423,416$ & 53.7 & $14,558,860$ & 45.3 \\
\hline \multicolumn{5}{|l|}{ Type of consumed food } \\
\hline Always the wanted kind & $9,209,284$ & 56.3 & $7,642,011$ & 45.1 \\
\hline Not always the wanted kind & $12,354,274$ & 48.0 & $12,477,381$ & 45.6 \\
\hline Rarely the wanted kind & $2,615,689$ & 40.8 & $3,216,111$ & 48.0 \\
\hline
\end{tabular}

*all of them were significant with $p<0.001$. MW: federal minimum wage at the time of the date of 2008/2009 HBS (BRL 415.00). 
Table 2. Measures of discrimination of variables and quantification of categories, centroid coordinates, in the dimensions ( 1 and 2) of the model, for adults, by sex, Brazil (2008 to 2009).

\begin{tabular}{|c|c|c|c|c|c|c|c|c|}
\hline \multirow{5}{*}{ Variables } & \multicolumn{8}{|c|}{ Sex } \\
\hline & \multicolumn{4}{|c|}{ Male } & \multicolumn{4}{|c|}{ Female } \\
\hline & \multicolumn{2}{|c|}{ MD } & \multicolumn{2}{|c|}{ CC } & \multicolumn{2}{|c|}{ MD } & \multicolumn{2}{|c|}{ CC } \\
\hline & \multicolumn{8}{|c|}{ Dimensions } \\
\hline & 1 & 2 & 1 & 2 & 1 & 2 & 1 & 2 \\
\hline Age & 0.009 & 0.433 & & & 0.003 & 0.597 & & \\
\hline 20 to 29 years old & & & -0.120 & -1.305 & & & 0.015 & -1.568 \\
\hline 30 to 39 years old & & & -0.070 & 0.139 & & & 0.100 & -0.122 \\
\hline 40 to 49 years old & & & 0.079 & 0.483 & & & -0.033 & 0.704 \\
\hline 50 to 59 years old & & & 0.226 & 1.589 & & & -0.127 & 1.730 \\
\hline Income & 0.594 & 0.141 & & & 0.601 & 0.011 & & \\
\hline$\leq 1 / 2 \mathrm{MW}$ & & & -1.653 & 0.961 & & & 1.695 & 0.072 \\
\hline $1 / 2>M W<2$ & & & -0.293 & -0.539 & & & 0.258 & -0.151 \\
\hline$\geq 2 \mathrm{MW}$ & & & 1.317 & 0.360 & & & 1.341 & 0.209 \\
\hline Schooling & 0.381 & 0.479 & & & 0.378 & 0.393 & & \\
\hline 0 to 5 years & & & -0.817 & 1.203 & & & 0.812 & 1.294 \\
\hline 6 to 9 years & & & -0.316 & -1.106 & & & 0.470 & -1.646 \\
\hline 10 to 12 years & & & 0.414 & -0.969 & & & -0.306 & -0.919 \\
\hline$\geq 13$ years & & & 1.749 & 0.938 & & & -1.658 & 0.082 \\
\hline Color/ethnicity & 0.304 & 0.005 & & & 0.299 & 0.014 & & \\
\hline White & & & 0.764 & 0.112 & & & -0.737 & 0.183 \\
\hline Nonwhite & & & -0.710 & -0.104 & & & 0.736 & -0.183 \\
\hline Region & 0.317 & 0.017 & & & 0.284 & 0.047 & & \\
\hline North & & & 0.886 & -0.285 & & & 0.872 & -0.734 \\
\hline Northeast & & & -1.053 & 0.218 & & & 1.000 & -0.191 \\
\hline Southeast & & & 0.478 & -0.092 & & & -0.450 & 0.101 \\
\hline South & & & 0.848 & 0.214 & & & -0.837 & 0.577 \\
\hline Center-West & & & 0.191 & -0.384 & & & -0.141 & -0.340 \\
\hline Amount of consumed food & 0.434 & 0.089 & & & 0.438 & 0.033 & & \\
\hline Usually not sufficient & & & -1.427 & 1.327 & & & 1.508 & 0.715 \\
\hline Sometimes not sufficient & & & -1.045 & -0.436 & & & 1.032 & -0.318 \\
\hline Always sufficient & & & 0.668 & -0.007 & & & -0.676 & 0.033 \\
\hline Type of consumed food & 0.405 & 0.118 & & & 0.423 & 0.035 & & \\
\hline Always the wanted kind & & & 1.107 & 0.261 & & & -1.145 & 0.118 \\
\hline Not always the wanted kind & & & -0.373 & -0.441 & & & 0.362 & -0.225 \\
\hline Rarely the wanted kind & & & -1.329 & 1.101 & & & 1.414 & 0.621 \\
\hline Body mass index & 0.079 & 0.069 & & & 0.003 & 0.323 & & \\
\hline Eutrophic & & & -0.373 & -0.409 & & & -0.072 & -0.799 \\
\hline Overweight & & & 0.375 & 0.411 & & & 0.085 & 0.948 \\
\hline
\end{tabular}

MW: federal minimum wage. MD: measures of discrimination. CC: coordinates of centroids. Values in bold refer to the variables (and therefore the categories) whose measures of discrimination were close to or higher than the values of dimension inertia. 


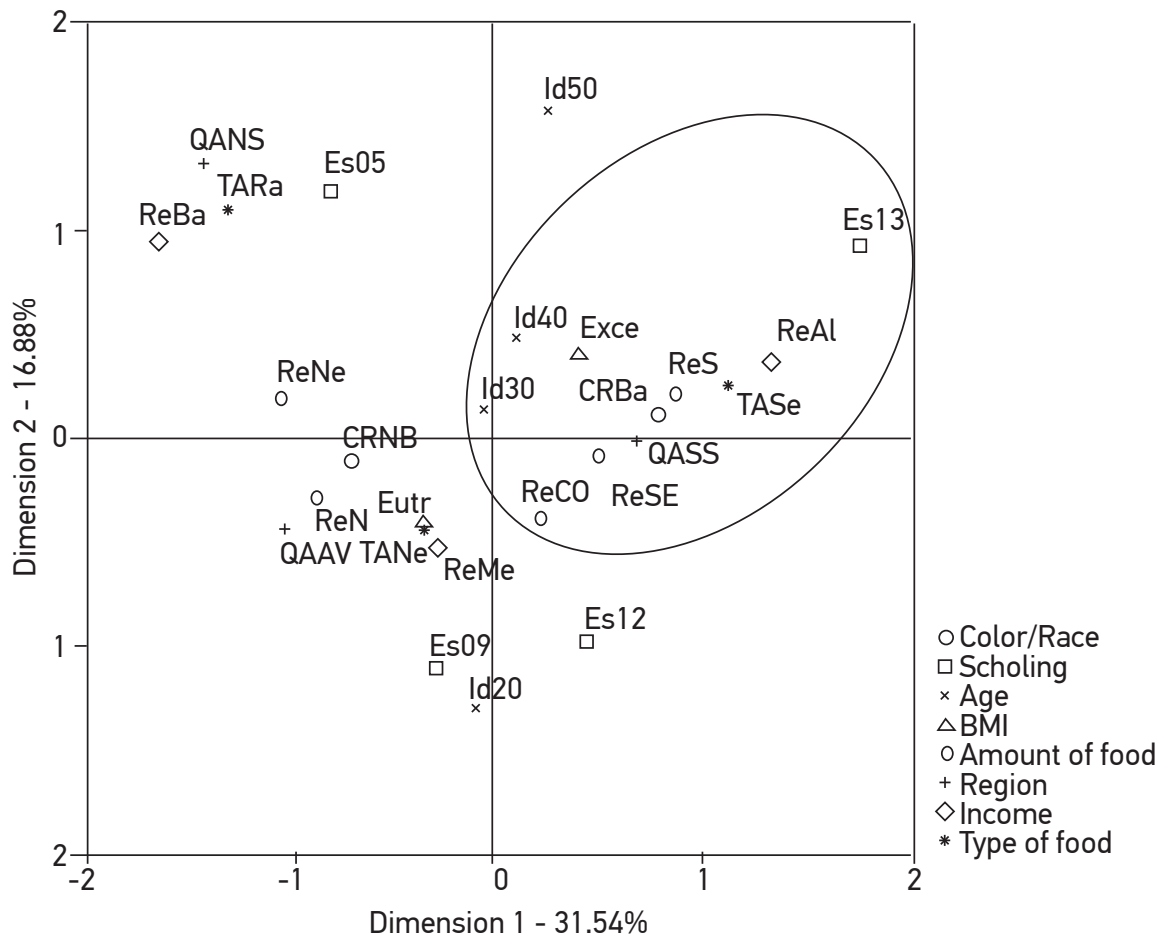

\begin{tabular}{c|c}
\multicolumn{2}{|c}{ CAPTION } \\
\hline Abbreviation & Categoria da variável \\
\hline Age \\
\hline Id20 & 20 to 29 years old \\
\hline Id30 & 30 to 39 years old \\
\hline Id40 & 40 to 49 years old \\
\hline Id50 & 50 to 59 years old \\
\hline Income & \\
\hline ReBa & $1 / 2>1 / 2 \mathrm{MW}$ \\
\hline ReMe & $\geq 2 \mathrm{MW}$ \\
\hline ReAl & \\
\hline Schooling & 0 to 5 years \\
\hline Es05 & 6 to 9 years \\
\hline Es09 & 10 to 12 years \\
\hline Es12 & $\geq 13$ years \\
\hline Es13 & \\
\hline Color/ethnicity & White \\
\hline CRBa & Nonwhite \\
\hline CRNB &
\end{tabular}

\begin{tabular}{|c|c|}
\hline \multicolumn{2}{|r|}{ CAPTION } \\
\hline Abbreviation & Categoria da variável \\
\hline \multicolumn{2}{|l|}{ Region } \\
\hline ReN & North \\
\hline ReNE & Northeast \\
\hline ReSE & Southeast \\
\hline $\operatorname{ReS}$ & South \\
\hline $\mathrm{ReCO}$ & Center-West \\
\hline \multicolumn{2}{|c|}{ Amount of consumed food } \\
\hline QANS & Usually not sufficient \\
\hline QAAV & Sometimes not sufficient \\
\hline QASS & Always sufficient \\
\hline \multicolumn{2}{|c|}{ Type of consumed food } \\
\hline TASe & Always the wanted kind \\
\hline TANe & Not always the wanted kind \\
\hline TARa & Rarely the wanted kind \\
\hline \multicolumn{2}{|c|}{ Body Mass Index } \\
\hline Eutr & Eutrophic \\
\hline Exce & Overweight \\
\hline
\end{tabular}

BMI: body mass index.

Figure 1. Visualization of socioeconomic and demographic characteristics of the Brazilian adult male population through the graph set generated by multiple correspondence analysis between dimensions 1 and 2 (Brazil, 2008/2009). 


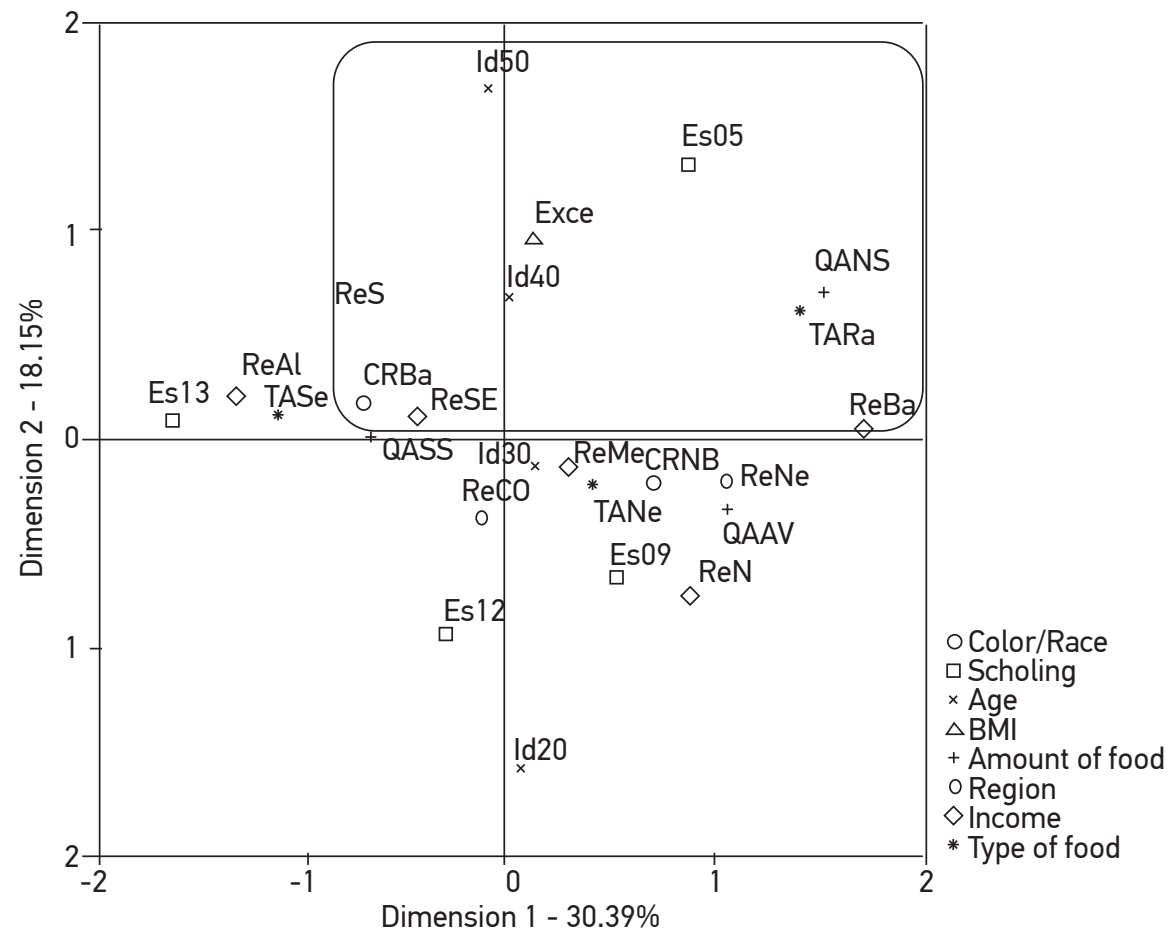

\begin{tabular}{c|c}
\hline \multicolumn{2}{|c}{ CAPTION } \\
\hline Abbreviation & Categoria da variável \\
\hline Age & \\
\hline Id20 & 20 to 29 years old \\
\hline Id30 & 30 to 39 years old \\
\hline Id40 & 40 to 49 years old \\
\hline Id50 & 50 to 59 years old \\
\hline Income & $\leq 1 / 2 \mathrm{MW}$ \\
\hline ReBa & $1 / 2>$ MW $<2$ \\
\hline ReMe & $\geq 2$ MW \\
\hline ReAl & 0 to 5 years \\
\hline Schooling & 6 to 9 years \\
\hline Es05 & 10 to 12 years \\
\hline Es09 & $\geq 13$ years \\
\hline Es12 & \\
\hline Es13 & White \\
\hline Color/ethnicity & Nonwhite \\
\hline CRBa &
\end{tabular}

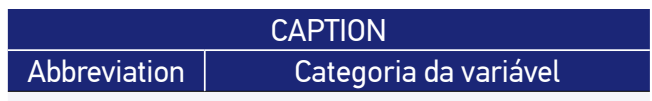

\begin{tabular}{c|c}
\multicolumn{2}{c}{ Region } \\
\hline ReN & North \\
\hline ReNE & Northeast \\
\hline ReSE & Southeast \\
\hline $\operatorname{ReS}$ & South \\
\hline $\operatorname{ReCO}$ & Center-West
\end{tabular}

Amount of consumed food

\begin{tabular}{c|c} 
QANS & Usually not sufficient \\
\hline QAAV & Sometimes not sufficient \\
\hline QASS & Always sufficient \\
\hline
\end{tabular}

Type of consumed food

\begin{tabular}{l|l} 
TASe & Always the wanted kind
\end{tabular}

TANe Not always the wanted kind

TARa Rarely the wanted kind

\begin{tabular}{c|c}
\hline \multicolumn{2}{c}{ Body Mass Index } \\
\hline Eutr & Eutrophic \\
\hline Exce & Overweight
\end{tabular}

BMI: body mass index.

Figure 2. Visualization of socioeconomic and demographic characteristics of the Brazilian adult female population through the graph set generated by multiple correspondence analysis between dimensions 1 and 2 (Brazil, 2008/2009). 
the effectiveness of MCA for the standardized and similar distribution of these indicators, or reduced the possibility of selection bias, therefore improving the representativeness of the sample. The proposed method based on MCA distinguished the relationship of the groups placed in separated quadrants, with different characteristics.

This analysis revealed a worrisome scenario, mainly illustrated by the condition that, in practically all of the categories of the analyzed age groups, there was correspondence with overweight, thus implying potential over-risk of morbidity and mortality of the possible associations with overweight in a significant contingent of the Brazilian adult population. These results are consistent and in agreement with data from the Telephonebased Surveillance of Risk and Protective Factors for Chronic Diseases (VIGITEL) ${ }^{16}$, in frequencies of overweight and obesity in Brazil. A possible justification for such finding is related to the common aging process, which affects physiological aspects associated with the accumulation of body fat, like, for instance, the reduced metabolism and hormonal changes that can contribute with the increasing levels of body fat ${ }^{13}$.

In this sense, facing the epidemic progress of overweighr rates in these age groups in Brazil is a major challenge for administrators, professionals and researchers in the field of nutritional epidemiology, thus translating a process of intense changes in proximal factors, in the causal network of the several problems experienced in the past few years in Brazil, reported by changes in dietary habits and practice of physical activity, besides more distal factors regarding socioeconomic status. This implies the need for further investigations and understanding in this dynamic and current stage of the nutritional transition in the country, in order to amplify and integrate actions from several sectors in the national scenario to face overweight control, as well as to maintain the control over the nutritional status of the Brazilian adult population aged more than 20 years old.

In Brazil, the nutritional transition is taking place at the same time as the sequels of nutritional deficiencies. In general, the relationship between rates of overweight and social stratum is inverse: the poorest residents are characterized as the most vulnerable to such a process, due to low schooling, precarious purchasing power to buy healthy foods and less availability of places and time for physical activities ${ }^{17}$. This would lead to increasing prevalence of chronic non-communicable diseases in the world ${ }^{1}$ and overweight, which, in the country, is different between genders: it is more common among men from all income levels and among women with higher levels ${ }^{12}$.

The negative aspects of dietary habits, especially in Brazil, in the end of the first decade of the $21^{\text {st }}$ century, indicate the need to prioritize public policies promoting a healthy diet ${ }^{18}$, including efforts to solve problems of SAN, which can influence overweight rates $^{19}$. In this study, based on information referring to SAN, on subjective matters of life conditions based on studies from the World Bank about this specific field ${ }^{20}$, which are useful to establish limits and criteria to measure or establish poverty lines of populations $^{21}$, a correlation between genders, in the opposite direction, was presented, regarding sufficiency (amoung) - sufficient, as usual; and usually not sufficient, and 
satisfaction (quality) - always the wanted type; and rarely the wanted type of consumed foods for men and women, respectively.

The aforementioned data, proposed as being good predictors of the real perception of individuals about essential factors for the quality of life of people ${ }^{22}$, may favor the increasing approaches of studies regarding life conditions, which complemente other technical and scientific evaluations addressed to analyzing nutritional patterns or other subjects. These can increase the possibilities of explanations related to health problems in adult populations referring to nutritional status ${ }^{12,16,21}$, especially concerning chronic diseases in adult populations, thus helping to understand the qualitative aspects of the diet, influenced by nutritional transition, thus implying the increasing prevalence of overweight, which is growing together with physical inactivity and morbimortality of chronic noncommunicable disease ${ }^{23-26}$.

The correspondence of overweight was demonstrated both in individuals with low and high schooling in thi study. Schooling is considered to be a proxy of economic status, and is constantly reported in studies about inequalities in health ${ }^{27}$. Besides, studies indicate that people with low schooling are more prone to the reflexes of overweight ${ }^{7}$, and more vulnerable to dietary restrictions. Then, children coming from environments of food insecurity tend to present sequels of protein-energy malnutrition, with reflexes in adulthood $^{12}$. Because of that, it is assumed that measures related to providing access to all, regardless of schooling and purchasing power, to information about the determinants and consequences of overweight, must be seen as possible strategies to prevent and control the disease ${ }^{28}$. These measures include public policies about the human right to adequate food addressed to people who cannot access it easily.

By assessing the quadrants, the results of this investigation indicated the correlation of overweight with the geographic regions South, Southeast and Center-West, which are the most developed ones in the country in social and economic terms, thus corroborating findings in literature ${ }^{7,16}$. In mid-income countries, like Brazil, economic development is associated with some characteristics considered to be obesigenic, such as sedentary lifestyle, in general, allied to the insufficient practice of physical exercises, daily stress, inadequate dietary habits and more access to food ${ }^{29}$.

Ethnic and racial disparities in health found in many countries, including Brazil, can be explained by socioeconomic issues that have been present for many generations ${ }^{30,31}$. These disparities create groups that are especially exposed to risks, but their dynamics is complex, therefore, it is also necessary to promote debates in the Brazilian public health field ${ }^{32}$.

In this contexto, it is relevant to analyze and interpret data regarding color/ethnicity, which are scarse in the national epidemiological literature; in other countries, like the USA and England, however, this variable has been important in the study of health matters ${ }^{33}$. In this study, it was possible to verify that white individuals were in the same overweight quadrant. A possible justification for that can be focused on socioeconomic level, because in Brazil white people compose the part of population with more financial resources in the different geographic regions ${ }^{34}$. It is also possible to speculate that white adults have more 
access to electronic devices, such as television and computer, which increases the chances of adopting sedentary lifestyles; therefore, the chances of overweight rates increase ${ }^{29}$.

One of the limitations of this study was the use of secondary data, which are prone to problems regarding the record of information. However, the team that performed data collection and record of information was trained by specialized technicians to decreased the chances of error.Besides, the cross-sectional design of the study does not allow establishing cause-and-effect relationships between independent and dependent variables. However, crosssectional studies are relevant for estimating measures that are useful to assess the weight of the disease in the community. They are valuable for the planning of the health service ${ }^{35}$. However, using the information in POF enables to subsidize public policies in the social field to improve the conditions of the population, including thematic publc polices in the fields of nutrition, dietary guidance and public health nationally ${ }^{12}$.

\section{CONCLUSION}

The joint relationships between overweight and socioeconomic and demographic conditions, observed by the MCA technique - which was adequate to identify the overweight profile in the Brazilian adult population aged from 20 to 59 years old, of both genders -, suggest an alarming situation. Correlations were presented in almost all of the age groups, in the most socially and economically developed regions of the country, among white people, those with low income (women) and high income (men), and, finally, among the respondents to subjective questions regarding life conditions in terms of SAN. These questions were related to sufficiency and satisfaction of the consumed foods in terms of quantity; sufficient, as usual (men); and usually not sufficient (women); and always the wanted type (men) and rarely the wanted type (women) regarding the quality of the food, respectively. In this sense, the development of public health strategies and/or programs to prevent health problems related to overweight among Brazilian adults is suggested.

\section{REFERENCES}

1. Popkin MB, Adair LS, NQ SW. Global nutrition transition and the pandemic of obesity in developing countries. Nutr Rev 2012; 70(1): 3-21.

2. Stevens GA, Singh GM, Lu Y, Danaei G, Lin JK, Finucane $\mathrm{MM}$, et al. National, regional, and global trends in adult overweight and obesity prevalence. Popul Health Metr 2012; 10(1): 22.

3. Wang H, Dwyer-Lindgren L, Lofgren KT, Rajaratnam JK, Marcus JR, Levin-Rector A, et al. Age-specific and sex-specific mortality in 187 countries, 1970-2010: a systematic analysis for the Global Burden of Disease Study 2010. Lancet 2012; 380(9859): 2071-94.
4. Doak CM, Wijnhoven TM, Schokker DF, Visscher TL, Seidell JC. Age standardization in mapping adult overweigth and obesity trends in the WHO European Region. Obes Rev 2012; 13(2): 174-91.

5. Wang H, Wang J, Liu MM, Wang D, Liu YQ, Zhao Y, et al. Epidemiology of general obesity, abdominal obesity and related risk factors in urban adults from 33 communities of northeast china: the CHPSNE study. BMC Public Health (Online) 2012; 12: 967.

6. Schiller JS, Lucas JW, Peregoy JA. Summary health statistics for U.S. adults: national health interview survey, 2011. Vital Health Stat 10 2012; (256): 1-218. 
7. Silva VS, Petroski EL, Souza I, Silva DA. Prevalência e fatores associados ao excesso de peso em adultos no Brasil: um estudo de base populacional em todo território nacional. Rev Bras Cienc Esporte 2012; 34(3): 713-26.

8. Gigante DP, França GV, Sardinha LM, Iser BP, Meléndez GV. Variação temporal na prevalência de excesso de peso e obesidade em adultos: Brasil, 2006 a 2009. Rev Bras Epidemiol 2011; 14(Supl 1): 157-65.

9. Sá NN, Moura EC. Excesso de peso: determinantes sociodemográficos e comportamentais em adultos, Brasil, 2008. Cad Saúde Pública 2011; 27(7): 1380-92.

10. Rohrmann S, Steinbrecher A, Linseisen J, Hermann S, May A, Luan J, et al. The association of education with long-term weight change in the EPIC-PANACEA cohort. Eur J Clin Nutr 2012; 66(8): 957-63.

11. Greenacre MJ. Correspondence analysis. WIREs Comp Stat 2010; 2(5): 613-9.

12. Instituto Brasileiro de Geografia e Estatística (IBGE). Pesquisa de orçamentos familiares 20082009: antropometria e estado nutricional de crianças, adolescentes e adultos no Brasil. Rio de Janeiro; 2010.

13. World Health Organization (WHO). Obesity: preventing and managing the global epidemic. Report of a WHO Consultation on Obesity. Geneva; 1998 (WHO - Technical Report Series, 894).

14. Pestana MH, Gageiro JN. Análise de dados para ciências sociais: a complementaridade do SPSS. 4 ed. Lisboa: Edições Silabo; 2005.

15. Statistical Package for the Social Sciences. IBM SPSS statistics 20 core system user's guide. Chicago: SPSS; 2011.

16. Brasil. Ministério da Saúde. Secretaria de Vigilância em Saúde. Vigitel Brasil 2011: vigilância de fatores de risco e proteção para doenças crônicas por inquérito telefônico. Brasília: Ministério da Saúde; 2012. 132p. Disponível em: http:/ /bvsms.saude.gov.br/bvs/publicacoes / vigitel_brasil_2011_fatores_risco_doencas_cronicas. pdf (Acessado em 15 de fevereiro de 2014).

17. Jones-Smith JC, Gordon-Larsen P, Siddiqi A, Popkin $\mathrm{BM}$. Is the burden of overweight shifting to the poor across the globe? Time trends among women in 39 low- and middle-income countries (1991-2008). Int J Obes 2012; 36(8): 1114-20.

18. Levy RB, Claro RM, Mondini L, Sichieri R, Monteiro CA. Distribuição regional e socioeconômica da disponibilidade domiciliar de alimentos no Brasil em 2008-2009. Rev Saúde Pública 2012; 46(1): 6-15.

19. Santos JV, Gigante DP, Domingues MR. Prevalência de insegurança alimentar em Pelotas, Rio Grande do Sul, Brasil, e estado nutricional de indivíduos que vivem nessa condição. Cad Saúde Pública 2010; 26(1): 41-9.
20. Grosh ME, Glewwe P. The world bank's living standars measurement study household surveys. J Econ Perspect 1998; 12(1): 187-96.

21. Maia GA. Relative income, inequality and subjective wellbeing: evidence for Brazil. Soc Indic Res 2013; 113: 1193-1204.

22. Attanasio OP. Expectations and perceptions in developing countries: their measurement and their use. Am Econ Rev 2009; 99(2): 87-92.

23. Mendonça CP, Anjos LA. Aspectos das práticas alimentares e da atividade física como determinantes do crescimento do sobrepeso-obesidade no Brasil. Cad Saúde Pública 2004; 20(3): 698-709.

24. Brasil. Ministério da Saúde. Secretaria de Vigilância em Saúde. Departamento de Análise de Situação de Saúde. Plano de ações estratégicas para o enfrentamento das doenças crônicas não transmissíveis (DCNT) no Brasil 2011-2022. Brasília: Ministério da Saúde; 2011. 148p. ISBN 978-85-334-1831-8. Disponível em: http://www. fnde.gov.br/arquivos / category/116-alimentacaoescolar?download=7897: plano-de-acoes-estrategicaspara-o-enfrentamento-das-dcnt-no-brasil (Acessado em 15 de fevereiro de 2014).

25. Malta DC, Morais Neto OL, Silva Junior JB. Apresentação do plano de ações estratégicas para o enfrentamento das doenças crônicas não transmissíveis no Brasil, 2011 a 2022. Epidemiol Serv Saúde 2011; 20(4): 425-38.

26. Schmidt MI, Duncan BB, Silva GA, Menezes AM, Monteiro CA, Barreto SM, et al. Chronic noncommunicable diseases in Brazil: burden and current challenges. Lancet 2011; 377(9781): 1949-61.

27. Silva DA, Peres KG, Boing AF, González-Chica DA, Peres MA. Clustering of risk behaviors for chronic noncommunicable diseases: a populationbased study in southern Brazil. Prev Med 2013; 56(1): 20-4.

28. Monteiro CA, Moura EC, Conde WL, Popkin BM. Socioeconomic status and obesity in adult populations of developing countries: a review. Bull World Health Organ 2004; 82(12): 940-6.

29. Wells JC, Marphatia AA, Cole TJ, McCoy D. Associations of economic and gender inequality with global obesity prevalence: understanding the female excess. Soc Sci Med 2012; 75(3): 482-90.

30. Chor D, Faerstein E, Kaplan GA, Lynch JW, Lopes CS. Association of weight change with ethnicity and life course socioeconomic position among Brazilian civil servants. Int J Epidemiol 2004; 33(1): 100-6. 
31. Pearce N, Foliaki S, Sporle A, Cunningham C. Genetics, race, ethnicity, and health. BMJ 2004; 328(7447): 1070-2.

32. Chor D. Desigualdades em saúde no Brasil: é preciso rer raça. Cad Saúde Pública 2013; 29(7): 1272-5.

33. Nazroo JY. The structuring of ethnic inequalities in health: economic position, racial discrimination, and racism. Am J Public Health 2003; 93(2): 277-84.
34. Boing AC, Bertoldi AD, Peres KG. Socioeconomic inequalities in expenditures and income committed to the purchase of medicines in Southern Brazil. Rev Saúde Pública 2011; 45(5): 897-905.

35. Gordis L. Epidemiologia. 4 ed. Rio de Janeiro: Revinter; 2010.

Received on: 02/26/2014

Final version presented on: 10/27/2014

Accepted on: 11/22/2014 